\title{
Prawne instrumenty WSPierające bezpieczeństwo EPIDEMICZNE BIORCÓW LUDZKICH KOMÓREK, TKANEK I NARZĄDÓW
}

Wolą ustrojodawcy, której dał wyraz w art. 68 ust. 4 ab initio Konstytucji Rzeczypospolitej Polskiej ${ }^{1}$, władzom publicznym został powierzony obowiązek zwalczania chorób epidemicznych. Adresatem przywołanego zadania są wszystkie władze publiczne, niezależnie od płaszczyzny ich działania, a więc zarówno centralne, jak i terenowe, w szczególności, zważywszy zasadę pomocniczości w wykonywaniu zadań publicznych, samorządowe.

W doktrynie panuje zgoda co do tego, że art. 68 ust. 4 Konstytucji został sformułowany jako tzw. norma programowa ${ }^{2}$, wyznaczająca cele działania władzy publicznej.

Posługując się argumentem a rubrica, można zasadnie stwierdzić, że ustawa zasadnicza czyni beneficjentem postanowień płynących z przywołanej normy konstytucyjnej ogół społeczeństwa, które powinno być chronione przed chorobami epidemicznymi, niezależnie od statusu jednostki wchodzącej w skład społeczeństwa w systemie ubezpieczenia zdrowotnego.

* Dr nauk prawn., Katolicki Uniwersytet Lubelski Jana Pawła II, kamias@kul.pl.

${ }^{1}$ Konstytucja Rzeczypospolitej Polskiej z dnia 2 kwietnia 1997 r., Dz.U. Nr 78, poz. 483 z późn. zm.; dalej: Konstytucja.

${ }^{2}$ L. Bosek, Komentarz do art. 68, [w:] M. Safjan, L. Bosek (red.), Konstytucja RP. Tom I. Komentarz Art. 1-86, Warszawa 2016, s. 1526; jakkolwiek trzeba podkreślić, że w doktrynie utorował sobie drogę pogląd, zgodnie z którym przepis ten, odczytywany z pozostałymi ustępami art. 68 ustawy zasadniczej jako całość, gwarantuje minimum praw podmiotowych, zob. J. Trzciński, M. Wiącek, Komentarz do art. 68, [w:] L. Garlicki, M. Zubik (red.), Konstytucja Rzeczypospolitej Polskiej. Komentarz. Tom II, Warszawa 2016, s. 732-738. 
Jednocześnie jednak warto zauważyć, że Konstytucja nie definiuje ani pojęcia "zwalczanie", ani "choroby epidemiczne". Terminy te mają charakter autonomicznych pojęć konstytucyjnych, które, jak wskazuje sąd konstytucyjny, nie mogą być rozumiane przez pryzmat przyjętych rozwiązań ustawowych ${ }^{3}$.

Przystępując do rekonstrukcji treści wyrażenia „zwalczanie chorób epidemicznych", trzeba zaznaczyć, że oprócz art. 68 ust. 4 Konstytucji, termin „,zwalczanie” został ulokowany w ustawie zasadniczej jeszcze tylko w jednym miejscu, mianowicie w jej art. 65 ust. 5. Przepis ten zawiera programowe zobowiązanie władzy publicznej do prowadzenia takiej polityki, której efektem będzie pełne, produktywne zatrudnienie poprzez realizowanie programów zwalczania bezrobocia. Kierując się dyrektywą wykładni językowej, „,nie można nadawać identycznym sformułowaniom $\mathrm{w}$ ramach tego samego aktu prawnego różnego znaczenia, jeżeli z tego aktu nie wynikają wskazówki, pozwalające na takie różne rozumienie tych samych sformułowań poszczególnych norm"4. Innymi słowy, można przyjąć, iż ustrojodawca posłużył się w art. 65 ust. 5 oraz art. 68 ust. 4 pojęciem „zwalczanie” w tożsamym znaczeniu. Uwzględniając powyższe oraz to, że Trybunał Konstytucyjny nie wypowiedział się dotąd co do rozumienia rzeczownika „zwalczanie” na kanwie art. 68 ust. 4 ustawy zasadniczej, zasadne jest przywołanie trybunalskich ustaleń poczynionych w świetle art. 65 ust. 5 Konstytucji. Sąd konstytucyjny zwraca uwagę, że z postanowień konstytucyjnych wynika, iż programy zwalczania bezrobocia obejmują "organizowanie i wspieranie poradnictwa i szkolenia zawodowego oraz robót publicznych i prac interwencyjnych", przy czym wyliczenie to ma charakter przykładowy ${ }^{5}$ (ustrojodawca posługuje się sformułowaniem „w tym”). Zwalczanie bezrobocia obejmuje więc zarówno instrumenty zapobiegawcze (poradnictwo i szkolenie zawodowe), jak i następcze (organizowanie robót publicznych). Przenosząc powyższe stwierdzenia na grunt rozważań odnoszonych do ustalenia treści terminu „zwalczanie chorób epidemicznych", należy podnieść, że pojęcie „zwalczanie” nie odnosi się tylko do przyjmowania środków o charakterze represyjnym, jako reakcja na zaistniałą i zdiagnozowaną "chorobę epidemiczną", ale także

\footnotetext{
${ }^{3}$ Por. wyrok Trybunał Konstytucyjnego z 25 lipca 2013 r., P 56/11.

${ }^{4}$ K. Opałek, J. Wróblewski, Zagadnienia teorii prawa, Warszawa 1969, s. 247.

${ }^{5}$ Por. wyroki Trybunału Konstytucyjnego z 24 lutego 2004 r., K 54/02, i z 10 stycznia 2005, K 31/03.
} 
środków prewencyjnych, mających za zadanie ubiegać aktualizację choroby epidemicznej.

Należy więc zgodzić się ze stanowiskiem przedstawicieli doktryny, iż na podstawie tego przepisu „władze publiczne mają obowiązek podejmowania działań prewencyjnych, których celem jest zapobieganie powstawaniu i rozprzestrzenianiu chorób epidemicznych" ${ }^{\prime 6}$. Co warte odnotowania, Konstytucja pozostawia zarazem organom władzy publicznej swobodę w wyborze metod i środków mających służyć realizacji tych celów.

Jakkolwiek art. 68 ust. 4 Konstytucji należy do tej grupy przepisów formułujących nakazy podejmowania przez władzę publiczną określonych zadań czy programów, z których nie wynika obowiązek ich realizacji poprzez wydanie ustawy, to w perspektywie kompetencji władzy ustawodawczej przywołaną regulację konstytucyjną trzeba postrzegać m.in. jako obowiązek zapewnienia takiego kontekstu prawnego i społecznego, by usuwać zewnętrzne zagrożenia zdrowia jednostki wynikające z chorób epidemicznych.

Przechodząc do ustalenia treści pojęcia chorób epidemicznych, wypada przede wszystkim wskazać, że wobec braku definicji konstytucyjnej należy odwołać się w tym zakresie do dorobku aktualnej wiedzy medycznej. Wedle definicji proponowanej przez przedstawicieli nauk medycznych epidemia to występowanie w określonym czasie i na określonym terenie przypadków zachorowań lub innych zjawisk związanych ze zdrowiem w liczbie większej niż oczekiwana ${ }^{7}$. Warto podkreślić, że pojęcie „epidemia" odnosi się do kwantytatywnego aspektu występowania chorób, nie do ich rodzaju (kwalifikator jakościowy). Tym samym uprawniony jest pogląd, że termin "choroby epidemiczne” jest szerszy niż pojęcie "choroby zakaźne”, zakres pierwszego z terminów może inkorporować zakres drugiego, nie są to jednak pojęcia synonimiczne ${ }^{8}$. Istnieją bowiem choroby niezakaźne, które mogą występować epidemicznie, np. cukrzyca. Naturalnie choroby zakaźne, a natura rei, posiadają większy potencjał, aby stać się jednocześnie epidemicznymi, jednak de lege lata pojęć tych nie należy utożsamiać.

${ }^{6}$ K. Prokop, Prawo do ochrony zdrowia w świetle art. 68 Konstytucji RP, [w:] T. Mróz, U. Drozdowska (red.), Uwarunkowania prawne, ekonomiczne $i$ socjologiczne funkcjonowania wybranych systemów ochrony zdrowia, Białystok 2011, s. 70 i przywoływana tam literatura.

7 M. Porta, A Dictionary of Epidemiology, Oxford 2008, s. 79.

8 Inaczej L. Bosek, Komentarz do art. 68, s. 1564. 
Powyższej tezie nie przeczy konstrukcja definicji epidemii przyjętej na gruncie ustawy z dnia 5 grudnia 2008 r. o zapobieganiu oraz zwalczaniu zakażeń i chorób zakaźnych u ludzi ${ }^{9}$, wedle której epidemią jest „wystąpienie na danym obszarze zakażeń lub zachorowań na chorobę zakaźną w liczbie wyraźnie większej niż we wcześniejszym okresie albo wystąpienie zakażeń lub chorób zakaźnych dotychczas niewystępujących". Jak bowiem wskazano wcześniej, zasady najwyższej mocy Konstytucji (art. 8) oraz autonomicznej interpretacji pojęć konstytucyjnych stoją na przeszkodzie odwołaniu się do ustawowej regulacji przy odczytywaniu treści konstytucyjnej ${ }^{10}$.

Warto również dodać, że działania ustawodawcy w zakresie zwalczania chorób epidemicznych znajdują także uzasadnienie $\mathrm{w}$ postanowieniach Europejskiej Karty Społecznej sporządzonej pod egidą Rady Europy w Turynie dnia 18 października 1961 r. ${ }^{11}$ Uwzględniając konieczność zapewnienia skutecznego wykonywania prawa do ochrony zdrowia ${ }^{12}$, państwa-strony zobowiązały się do podjęcia bądź bezpośrednio, bądź we współpracy z organizacjami publicznymi lub prywatnymi stosownych środków zmierzających zwłaszcza do zapobiegania, tak dalece, jak to możliwe, chorobom epidemicznym, endemicznym i innym (art. 11 pkt 3). Niemal analogiczne zobowiązanie przyjęły państwa sygnatariusze Międzynarodowego Paktu Praw Gospodarczych, Społecznych i Kulturalnych otwartego do podpisu w Nowym Jorku dnia 19 grudnia 1966 r. ${ }^{13} \mathrm{~W}$ jego art. 12 ust. 2 lit. c wskazały bowiem, iż kroki, ,jakie Państwa Strony niniejszego Paktu powinny podjąć dla osiągnięcia pełnego wykonania tego prawa [do korzystania z najwyższego osiągalnego poziomu ochrony zdrowia fizycznego i psychicznego - przyp. aut.], będą obejmowały środki konieczne do: $(\ldots)$ c) zapobiegania chorobom epidemicznym, endemicznym, zawodowym i innym oraz ich leczenia i zwalczania".

Podsumowując poczynione ustalenia, władze publiczne mają konstytucyjny obowiązek zwalczania chorób epidemicznych, który przez legis-

9 Tekst jedn., Dz.U. z 2016 r. poz. 1866 z późn. zm.; dalej u.z.z.z.ch.z.

${ }^{10} \mathrm{Z}$ zastrzeżeniem sytuacji, w której Konstytucja sama do regulacji ustawowej nie odsyła, z czym jednak nie mamy do czynienia na gruncie analizowanego problemu.

11 Dz.U. z 1999 r. Nr 8, poz. 667 z późn. zm.

${ }^{12}$ Będącego standardem zarówno konstytucyjnym, jak i wynikającym m.in. z art. 35 Karty Praw Podstawowych Unii Europejskiej (Dz. Urz. UE 2007, C 303, s. 1 ze sprost.).

${ }^{13}$ Dz.U. z 1977 r. Nr 38, poz. 169 z załącznikami. 
latywę będzie realizowany poprzez przyjęcie przepisów służących identyfikacji, zapobieganiu i zwalczaniu zaistniałych epidemii.

W polskiej przestrzeni badawczej problematyka zwalczania chorób epidemicznych analizowana jest głównie w perspektywie obowiązkowych szczepień ochronnych, przymusowego leczenia czy funkcjonowania Państwowej Inspekcji Sanitarnej czy Inspekcji Weterynaryjnej. Niniejsze opracowanie zostanie poświęcone wątkowi tych działań prawodawcy, które gwarantują bezpieczeństwo epidemiczne biorcom ludzkich komórek, tkanek i narządów.

Rozważania te należy rozpocząć stwierdzeniem, że przeszczepianie komórek, tkanek i narządów stanowi metodę leczenia należącą do kanonu aktualnej wiedzy medycznej ${ }^{14}$, zgodnie z którą lekarze powinni wykonywać swój zawód ${ }^{15}$. Jednocześnie jednak transplantacje nie tylko nie niosą ze sobą gwarancji sukcesu terapeutycznego, ale dodatkowo obciążone są ryzykiem przeniesienia do biorcy zakażenia bakteryjnego, wirusowego, grzybiczego czy nowotworu dawcy, zwiększając tym samym chorobowość i śmiertelność w społeczeństwie.

Ustawodawca, dostrzegając to niebezpieczeństwo i czyniąc w tym zakresie zadość zobowiązaniom międzynarodowym oraz obligacji wynikającej z art. 68 ust. 4 Konstytucji, przyjął szereg instrumentów, których wykorzystanie ma minimalizować transmisję czynnika chorobotwórczego od dawcy do biorcy.

Rekonstrukcja wspomnianych instrumentów jest o tyle skomplikowana, że przepisy dotyczące dawstwa komórek, tkanek i narządów ludzkich rozproszone są w kilku aktach prawnych. Po pierwsze, jest to ustawa z dnia 1 lipca 2005 r. o pobieraniu, przechowywaniu i przeszczepianiu komórek, tkanek i narządów ${ }^{16}$, której zakres normowania odnosi się do pobierania, przechowywania, przeszczepiania i zastosowania u ludzi komórek, w tym komórek krwiotwórczych szpiku, krwi obwodowej oraz krwi pępowinowej, tkanek i narządów pochodzących od żywego dawcy lub ze zwłok. Jednocześnie ustawa ta wyłącza swoje zastosowanie względem pobierania, przeszczepiania komórek rozrodczych, gonad, tkanek zarodkowych i płodowych oraz narządów rozrodczych lub ich części oraz

${ }^{14}$ J. Haberko, I. Uhrynowska-Tyszkiewicz, Ustawa o pobieraniu, przechowywaniu i przeszczepianiu komórek, tkanek i narządów. Komentarz, Warszawa 2014, LEX/El. nr 8916.

15 Por. art. 4 ustawy z dnia 5 grudnia 1996 r. o zawodach lekarza i lekarza dentysty (tekst jedn., Dz.U. z 2017 r. poz. 125 z późn. zm.; dalej: u.z.l.).

16 Tekst jedn., Dz.U. z 2017 r. poz. 1000, dalej: ustawa transplantacyjna. 
pobierania, przechowywania i dystrybucji krwi do celów jej przetaczania, oddzielenia jej składników lub przetworzenia w leki. Z tego względu, po drugie, w perspektywie tematu niniejszego opracowania, należy dokonać analizy przepisów ustawy z dnia 25 czerwca 2015 r. o leczeniu niepłodności ${ }^{17}$ oraz, po trzecie, ustawy z dnia 22 sierpnia 1997 r. o publicznej służbie $\mathrm{krwi}^{18}$.

Mechanizmy, które mają gwarantować epidemiczne bezpieczeństwo biorców, można usystematyzować w kilku grupach i wskazać, że odnoszą się one do podmiotów realizujących transplantacje oraz do dawców komórek, tkanek i narządów.

Odnosząc się do pierwszej ze wskazanych grup, należy podkreślić, że swoim zakresem normowania obejmują one zarówno warunki organizacyjne, jakim ma odpowiadać podmiot realizujący eksplantację i implantację komórek, tkanek i narządów, jak i przesłanki stawiane personelowi wykonującemu te zadania.

$\mathrm{Na}$ gruncie ustawy transplantacyjnej postępowanie dotyczące komórek, tkanek i narządów, polegające na: pobieraniu komórek, tkanek i narządów od żywych dawców - może być prowadzone wyłącznie w podmiotach leczniczych; pobieraniu narządów w celu przeszczepienia ze zwłok ludzkich - może być prowadzone wyłącznie w podmiotach leczniczych; pobieraniu komórek i tkanek ze zwłok ludzkich - może być prowadzone $\mathrm{w}$ podmiotach leczniczych ${ }^{19}$; przechowywaniu narządów może być prowadzone wyłącznie w podmiotach leczniczych wykonujących przeszczepienia; przeszczepianiu lub zastosowaniu u ludzi - może być prowadzone wyłącznie $\mathrm{w}$ podmiotach leczniczych ${ }^{20}$. Zastosowanie komórek rozrodczych i zarodków w procedurze medycznie wspomaganej prokreacji polegającej na przeniesieniu męskich komórek rozrodczych do organizmu biorczyni lub pozaustrojowym utworzeniu zarodków (zapłodnienie pozaustrojowe) i przeniesieniu utworzonych zarodków do organizmu biorczyni ${ }^{21}$ również odbywa się w ośrodku medycznie wspo-

17 Tekst jedn., Dz.U. z 2017 r. poz. 865; dalej: u.l.n.

18 Tekst jedn., Dz.U. z 2017 r. poz. 1371; dalej: u.p.s.k.

${ }_{19}$ Pobranie tkanek i komórek ze zwłok może także odbyć się w zakładach medycyny sądowej, zakładach anatomii patologicznej uczelni medycznych i uniwersytetów z wydziałem medycznym, instytutach badawczych, o których mowa $\mathrm{w}$ art. 3 ustawy z dnia 30 kwietnia 2010 r. o instytutach badawczych (tekst jedn., Dz.U. z 2017 r. poz. 1158 z późn. zm.) i zakładach pogrzebowych posiadających salę sekcyjną.

${ }^{20}$ Por. art. 36 ustawy transplantacyjnej.

${ }^{21}$ Por. art. 17 u.l.n. 
maganej prokreacji, będącym podmiotem leczniczym ${ }^{22}$. Przetoczenia krwi lub jej składników mogą dokonywać wyłącznie: lekarz wykonujący zawód w podmiocie leczniczym wykonującym działalność leczniczą w rodzaju stacjonarne i całodobowe świadczenia zdrowotne; na zlecenie lekarza pielęgniarka lub położna wykonująca zawód w podmiocie leczniczym wykonującym działalność leczniczą w rodzaju stacjonarne i całodobowe świadczenia zdrowotne, pod warunkiem że odbyła organizowane przez regionalne centrum, Wojskowe Centrum lub Centrum MSWiA odpowiednie przeszkolenie praktyczne i teoretyczne potwierdzone zaświadczeniem $^{23}$.

Ustalenie to pozwala na stwierdzenie, że wobec wymienionych powyżej podmiotów leczniczych należy stosować postanowienia ustawy o zapobieganiu oraz zwalczaniu zakażeń i chorób zakaźnych u ludzi dotyczące obowiązków przeciwdziałania zakażeniom, wynikające z art. 11 tej regulacji.

Przede wszystkim na kierownikach tych podmiotów leczniczych oraz na innych osobach udzielających świadczeń zdrowotnych ciąży powinność podejmowania działań zapobiegających szerzeniu się zakażeń i chorób zakaźnych. Działania te obejmują w szczególności: ocenę ryzyka wystąpienia zakażenia związanego z wykonywaniem świadczeń zdrowotnych; monitorowanie czynników alarmowych i zakażeń związanych z udzielaniem świadczeń zdrowotnych w zakresie wykonywanych świadczeń; opracowanie, wdrożenie i nadzór nad procedurami zapobiegającymi zakażeniom i chorobom zakaźnym związanym z udzielaniem świadczeń zdrowotnych, w tym dekontaminacji skóry i błon śluzowych lub innych tkanek, wyrobów medycznych, wyrobów medycznych do diagnostyki in vitro, wyposażenia wyrobów medycznych, wyposażenia wyrobów medycznych do diagnostyki in vitro i aktywnych wyrobów medycznych do implantacji oraz powierzchni pomieszczeń i urządzeń; stosowanie środków ochrony indywidualnej i zbiorowej w celu zapobieżenia przeniesieniu na inne osoby biologicznych czynników chorobotwórczych; wykonywanie badań laboratoryjnych oraz analizę lokalnej sytuacji epidemiologicznej w celu optymalizacji profilaktyki i terapii antybiotykowej; prowadzenie kontroli wewnętrznej $\mathrm{w}$ zakresie realizacji wymienionych działań.

\footnotetext{
${ }^{22}$ Art. 44 ust. $1 \mathrm{w}$ zw. $\mathrm{z}$ art. 2 ust. 1 pkt 18 u.l.n.

${ }^{23}$ Art. 21 ust. 1 u.p.s.k.
} 
Dodatkowo, w art. 12 ust. 1, ustawodawca nakłada na kierowników podmiotów leczniczych i osoby udzielające świadczeń zdrowotnych obowiązek prowadzenia dokumentacji realizacji przywołanych wyżej działań. Wykonanie obowiązków ustawowych zostało poddane kontroli organów Państwowej Inspekcji Sanitarnej ${ }^{24}$.

Kierownicy podmiotów leczniczych wykonujących działalność leczniczą w rodzaju świadczenia szpitalne zostali także zobligowani do wdrożenia i zapewnienia funkcjonowania w nich systemu zapobiegania i zwalczania zakażeń szpitalnych ${ }^{25}$. Ustawodawca zdeterminował elementy tego systemu, wskazując, że obejmuje on:

1) powołanie i nadzór nad działalnością zespołu i komitetu kontroli zakażeń szpitalnych;

2) ocenę ryzyka i monitorowanie występowania zakażeń szpitalnych i czynników alarmowych;

3) organizację udzielania świadczeń zdrowotnych, w sposób zapewniający:

a) zapobieganie zakażeniom szpitalnym i szerzeniu się czynników alarmowych,

b) warunki izolacji pacjentów z zakażeniem lub chorobą zakaźną oraz pacjentów szczególnie podatnych na zakażenia szpitalne,

c) możliwość wykonywania badań laboratoryjnych w ciągu całej doby,

d) wykonywanie badań laboratoryjnych, umożliwiających identyfikację biologicznych czynników chorobotwórczych wywołujących zakażenia i choroby zakaźne, oraz ich weryfikację przez podmioty weryfikujące wyniki badań laboratoryjnych,

e) ograniczenie narastania lekooporności biologicznych czynników chorobotwórczych w wyniku niewłaściwego stosowania profilaktyki i terapii antybiotykowej;

4) monitorowanie i rejestrację zakażeń szpitalnych i czynników alarmowych;

5) sporządzanie i przekazywanie właściwemu państwowemu inspektorowi sanitarnemu raportów o bieżącej sytuacji epidemiologicznej szpitala;

\footnotetext{
${ }^{24}$ Art. 13 u.z.z.z.ch.z.

${ }^{25}$ Art. 14 ust. 1 u.z.z.z.ch.z.
} 
6) zgłaszanie w ciągu 24 godzin potwierdzonego epidemicznego wzrostu liczby zakażeń szpitalnych właściwemu państwowemu inspektorowi sanitarnemu.

Nieco odmienne regulacje dotyczą jednostek organizacyjnych, w których pobierana jest krew i jej składniki, a także dokonywana jest preparatyka. Działalność ta jest dopuszczalna wyłącznie przez jednostki organizacyjne publicznej służby krwi, którymi są: regionalne centra krwiodawstwa i krwiolecznictwa, Wojskowe Centrum Krwiodawstwa i Krwiolecznictwa oraz Centrum Krwiodawstwa i Krwiolecznictwa utworzone przez ministra właściwego do spraw wewnętrznych ${ }^{26}$. Jednostki te są obowiązane do opracowania, wdrożenia i utrzymywania systemu jakości opartego na wymaganiach dobrej praktyki pobierania krwi i jej składników, badania, preparatyki, przechowywania, wydawania i transportu. System jakości obejmuje:

1) zarządzanie jakością, system zapewnienia jakości oraz stałe jego doskonalenie;

2) wymagania dotyczące personelu, pomieszczeń, sprzętu, dokumentacji, pobierania krwi i jej składników, badań, preparatyki, przechowywania, wydawania i transportu, kontroli niezgodności, kontroli wewnętrznych, kontroli jakości, wycofywania krwi i jej składników oraz działania naprawcze i zapobiegawcze;

3) wymagania dotyczące podnoszenia kwalifikacji personelu przez udział w systematycznych szkoleniach z zakresu krwiodawstwa i krwiolecznictwa;

4) kontrole jakości.

System jakości powinien gwarantować, że wszystkie procesy są uwzględnione we właściwych standardowych procedurach operacyjnych i przebiegają zgodnie z normami i specyfikacjami.

Zgodnie z art. 14a u.p.s.k., w jednostkach organizacyjnych publicznej służby krwi osoba kierująca komórką organizacyjną jest osobą odpowiedzialna, do której zadań należy m.in.: zapewnienie przestrzegania wymagań dobrej praktyki pobierania krwi i jej składników, preparatyki, badania, przechowywania oraz wydawania i transportu; zapewnienie, aby osoby zajmujące się pobieraniem, badaniem, preparatyką, przechowywaniem i wydawaniem krwi lub jej składników posiadały odpowiednie kwalifikacje i odbywały właściwe, regularne szkolenia; zapewnienie zgodności

${ }^{26}$ Por. art. 14 ust. 1 u.p.s.k. 
systemu zapewnienia jakości obowiązującego w jednostkach organizacyjnych publicznej służby krwi, dokumentacji oraz identyfikowalności dawcy krwi z wymaganiami określonymi w ustawie o publicznej służbie krwi.

W związku z tym, że pobranie tkanek i komórek (ustawodawca wyłączył z możliwości bankowania narządy) nierzadko następuje niebezpośrednio względem ich implantacji, tworzy się banki komórek i tkanek, których zadaniem jest gromadzenie, przetwarzanie, sterylizacja, przechowywanie, dystrybucja, dopuszczanie do obiegu lub prowadzenie działalności przywozowej tkanek i komórek przeznaczonych do przeszczepienia lub zastosowania u ludzi ${ }^{27}$. W przypadku zarodków i komórek rozrodczych tworzone są banki komórek rozrodczych i zarodków ${ }^{28}$. Oba rodzaje banków zobligowane są ustawowo do zapewnienia bankowanym w nich materiałom jakości i bezpieczeństwa ${ }^{29}$.

Z perspektywy podjętego tematu bezpieczeństwa epidemicznego biorców przeszczepów szczególnego znaczenia nabiera system monitorowania sytuacji, w których wystąpiło lub zaktualizowało się ryzyko transmisji czynnika chorobotwórczego z dawcy na biorcę.

Zarówno ustawa transplantacyjna, jak i ustawa o leczeniu niepłodności posługują się pojęciami istotnego zdarzenia niepożądanego ${ }^{30}$ oraz istotnej reakcji niepożądanej ${ }^{31}$. Na gruncie ustawy transplantacyjnej istotne zdarzenie niepożądane to nieprzewidziane zdarzenie związane z pobieraniem, gromadzeniem, przetwarzaniem, testowaniem, przechowywaniem, dystrybucja dopuszczeniem do obiegu, przywozem, wywozem, działalnością przywozowa, przeszczepianiem komórek, tkanek lub narządów lub zastosowaniem u ludzi komórek lub tkanek, mogące prowadzić do przeniesienia się choroby zakaźnej, mogące powodować pogorszenie stanu zdrowia, potrzebę leczenia w szpitalu albo wydłużenie takiego leczenia, uszkodzenie ciała, niepełnosprawność, niezdolność do pracy, zagrożenie dla życia albo śmierć. W świetle ustawy o leczeniu niepłodności jest to natomiast „niepomyślne zdarzenie związane z pobraniem, przetwarzaniem, testowaniem, przechowywaniem, dystrybucją lub zastosowaniem u ludzi komórek rozrodczych lub zarodków, które może prowadzić do przeniesienia choroby zakaźnej, zagrożenia życia albo do śmierci,

\footnotetext{
27 Art. 25 ustawy transplantacyjnej.

28 Art. 45 u.1.n.

29 Por. art. 40-41 u.l.n. i art. 28-29 i art. 32 ustawy transplantacyjnej.

${ }^{30}$ Zob. art. 2 ust. 1 pkt 18 ustawy transplantacyjnej i art. 2 ust. 1 pkt 12 u.l.n.

31 Zob. art. 2 ust. 1 pkt 19 ustawy transplantacyjnej i art. 2 ust. 1 pkt 13 u.l.n.
} 
uszkodzenia ciała lub pogorszenia stanu zdrowia dawcy, biorczyni lub dziecka, które urodzi się w wyniku procedury medycznie wspomaganej prokreacji, lub które może spowodować potrzebę leczenia w szpitalu albo wydłużenie takiego leczenia, a także zdarzenie prowadzące do błędnego oznakowania lub pomylenia prawidłowo oznakowanych komórek rozrodczych lub zarodków".

Natomiast istotna reakcja niepożądana wedle ustawy transplantacyjnej oznacza nieprzewidzianą reakcję organizmu dawcy lub biorcy związaną z pobieraniem, gromadzeniem, przetwarzaniem, testowaniem, przechowywaniem, dystrybucja, dopuszczeniem do obiegu, przywozem, wywozem, działalnością przywozową przeszczepianiem komórek, tkanek lub narządów lub zastosowaniem u ludzi komórek lub tkanek, prowadzącą do przeniesienia się choroby zakaźnej, powodującą pogorszenie stanu zdrowia, potrzebę leczenia w szpitalu albo wydłużenie takiego leczenia, uszkodzenie ciała, niepełnosprawność, niezdolność do pracy, zagrożenie dla życia albo śmierć. W perspektywie ustawy o leczeniu niepłodności to niezamierzona reakcja organizmu dawcy lub biorczyni związana z pobieraniem lub zastosowaniem u ludzi komórek rozrodczych lub zarodków, powodująca zagrożenie życia albo śmierć, uszkodzenie ciała, niezdolność do samodzielnego życia, niepełnosprawność lub pogorszenie stanu zdrowia dawcy, biorczyni lub dziecka, które urodzi się w wyniku procedury medycznie wspomaganej prokreacji, lub mogąca powodować potrzebę leczenia w szpitalu albo wydłużenie takiego leczenia lub przeniesienie choroby zakaźnej.

Bliźniacze regulacje $\mathrm{w}$ przywołanych ustawach nie mogą dziwić, są bowiem efektem implementacji do polskiego systemu prawa dyrektywy 2004/23/WE Parlamentu Europejskiego i Rady z dnia 31 marca 2004 r. w sprawie ustalenia norm jakości i bezpiecznego oddawania, pobierania, testowania, przetwarzania, konserwowania, przechowywania i dystrybucji tkanek i komórek ludzkich ${ }^{32}$, której polski prawodawca dokonał, ignorując dyrektywę lege non distinguente, i spoza zakresu normowania ustawy transplantacyjnej wyłączył komórki rozrodcze, narządy rozrodcze i ich części, natomiast dyrektywa 2004/23/WE odnosi się do wszystkich komórek, tkanek i narządów ludzkich.

Również ustawa o publicznej służbie krwi posługuje się pojęciem poważnej niepożądanej reakcji, którą jest niezamierzona reakcja organi-

${ }^{32}$ Dz.Urz. UE L 102, s. 48 i n. z późn. zm.; dalej: dyrektywa 2004/23/WE. 
zmu dawcy krwi lub biorcy krwi związana z oddawaniem krwi lub jej składników lub ich przetoczeniem, prowadząca do śmierci, zagrożenia życia, utraty sprawności, pogorszenia stanu zdrowia lub powodująca hospitalizację lub chorobę albo ich przedłużenie ${ }^{33}$, oraz terminem "poważne niepożądane zdarzenie”, rozumianym jako „zdarzenie związane z pobieraniem, badaniem, preparatyka, przechowywaniem, wydawaniem i transportem krwi lub jej składników lub ich przetoczeniem, które mogłoby doprowadzić do śmierci, stanowić zagrożenie życia, spowodować utratę sprawności, pogorszenie stanu zdrowia lub hospitalizację lub chorobę albo ich przedłużenie" ${ }^{\prime 34}$.

Instrument $\mathrm{w}$ postaci obowiązku raportowania podmiotom zewnętrznym o istotnych zdarzeniach niepożądanych lub istotnej niepożądanej reakcji ma na celu zdiagnozowanie przyczyn tych zdarzeń i reakcji u biorców oraz wykluczenie ich w przyszłości.

W wypadku transfuzji krwi podmiot leczniczy wykonujący działalność leczniczą w rodzaju stacjonarne i całodobowe świadczenia zdrowotne jest obowiązany niezwłocznie, jednak nie później niż w terminie 24 godzin, powiadomić Instytut za pośrednictwem właściwej jednostki organizacyjnej publicznej służby krwi o każdym przypadku wystąpienia poważnego niepożądanego zdarzenia lub poważnej niepożądanej reakcji związanych z przygotowaniem do przetoczenia krwi i jej składników, w trakcie przetaczania krwi i jej składników lub po ich przetoczeniu oraz o każdym przypadku podejrzenia lub stwierdzenia choroby, która może być spowodowana przetoczeniem.

Jednostka organizacyjna publicznej służby krwi jest wówczas obowiązana przeprowadzić, we współdziałaniu z tym podmiotem leczniczym, postępowanie wyjaśniające $\mathrm{w}$ celu ustalenia przyczyny wystąpienia niepożądanych przypadków i podjąć działania zapobiegawcze ${ }^{35}$.

Zadaniem osoby odpowiedzialnej wyznaczonej w banku tkanek i komórek jest informowanie Krajowego Centrum Bankowania Tkanek i Komórek o każdym przypadku zaistnienia istotnego zdarzenia niepożądanego lub istotnej niepożądanej reakcji ${ }^{36}$.

Podmioty dokonujące pobierania, przechowywania i przeszczepiania komórek, tkanek i narządów mogą także (opcjonalnie) zgłosić Krajowej

\footnotetext{
${ }^{33}$ Por. art. 5 pkt 15 u.p.s.k.

${ }_{34}$ Art. 5 pkt 16 u.p.s.k.

${ }_{35}$ Art. 22 u.p.s.k.

${ }^{36}$ Zob. art. 28 ustawy transplantacyjnej.
} 
Radzie Transplantacyjnej istotne niepożądane reakcje i istotne zdarzenia niepożądane celem zaopiniowania przez Radę przestrzegania ustalonych procedur postępowania $\mathrm{w}$ zakresie pobierania, przechowywania i przeszczepiania komórek, tkanek i narządów oraz spełniania warunków wymaganych w ustalonym systemie zapewnienia jakości ${ }^{37}$.

Zgodnie z $§ 10$ rozporządzenia Ministra Zdrowia z dnia 21 października 2015 r. w sprawie niepowtarzalnego oznakowania i monitorowania komórek rozrodczych i zarodków ${ }^{38}$, w ramach monitorowania, każdy przypadek zaistnienia lub podejrzenia zaistnienia istotnego zdarzenia niepożądanego lub istotnej niepożądanej reakcji zgłasza się ministrowi właściwemu do spraw zdrowia drogą elektroniczną. Jednocześnie, bezpośrednio po dokonaniu zgłoszenia, osoba odpowiedzialna za jakość w ośrodku medycznie wspomaganej prokreacji oraz osoba odpowiedzialna za jakość w banku komórek rozrodczych i zarodków wszczyna postępowanie wyjaśniające przez powiadomienie odpowiednio kierownika ośrodka medycznie wspomaganej prokreacji albo kierownika banku komórek rozrodczych i zarodków.

W trakcie postępowania wyjaśniającego osoba odpowiedzialna za jakość w ośrodku medycznie wspomaganej prokreacji oraz osoba odpowiedzialna za jakość w banku komórek rozrodczych i zarodków ustala, czy doszło do istotnego zdarzenia niepożądanego lub istotnej niepożądanej reakcji i jakiego rodzaju jest to zdarzenie lub reakcja; określa, co mogło być przyczyną istotnego zdarzenia niepożądanego lub istotnej niepożądanej reakcji, oraz opisuje działania, które powinny być podjęte w celu zapobieżenia wystąpieniu $\mathrm{w}$ przyszłości podobnego istotnego zdarzenia niepożądanego lub istotnej niepożądanej reakcji.

Ustawowe wymagania dotyczące systemowego przygotowania jednostki organizacyjnej do bezpiecznego pobrania i podania komórek, tkanek czy narządów są tylko jednym z elementów „łańcucha bezpieczeństwa" epidemicznego dla biorcy. Kolejną gwarancję tworzy statuowany w art. 6 ust. 1 pkt 5 u.z.z.z.ch.z. obowiązek poddania się badaniom sanitarno-epidemiologicznym. Podlegają mu osoby podejmujące lub wykonujące prace, przy wykonywaniu których istnieje możliwość przeniesienia zakażenia lub choroby zakaźnej na inne osoby. Nie ulega więc wątpliwości, że krąg podmiotowy adresatów tej obligacji obejmuje osoby zatrudnione

\footnotetext{
${ }^{37}$ Art. 41 ust. 6 pkt 8 lit. b ustawy transplantacyjnej.

${ }^{38}$ Dz.U. poz. 1747.
} 
w podmiotach leczniczych i jednostkach publicznej służby krwi, bankach komórek, tkanek, komórek rozrodczych i zarodków uczestniczące w procedurze eksplantacji narządów, tkanek, pobieraniu komórek, krwi w celu jej przetoczenia oraz komórek rozrodczych czy implantacji zarodka. Personel medyczny i pomocniczy, mając kontakt z dawcą i biorca, może sam stać się transmitentem czynnika chorobotwórczego (przy założeniu deficytów w zakresie kontaminacji), jak również może być jego źródłem.

Jednocześnie warto zwrócić uwagę na to, że postanowienia ustawy o zapobieganiu oraz zwalczaniu zakażeń i chorób zakaźnych u ludzi stosuje się do zakażeń i chorób zakaźnych, których wykaz jest określony w załączniku do ustawy. Oznacza to, że obowiązek poddania się badaniom sanitarno-epidemiologicznym nałożony przez pracodawcę na personel medyczny nie dotyczy badań na obecność czynników chorobotwórczych spoza tej listy, dla przykładu, wirusa Epsteina-Barr (EBV). Tymczasem, wedle doniesień przedstawicieli nauk medycznych, 90-95\% populacji osób dorosłych ma dodatnie miano przeciwciał świadczące o przebytym zakażeniu $\mathrm{EBV}^{39}$.

Jak wspomniano wcześniej, przywołane instrumenty prawne nakierowane są na systemowe zapobieganie przeniesieniu czynnika chorobotwórczego z dawcy na biorcę. Dla konkretnego biorcy najistotniejsze znaczenie będzie miało zastosowanie $\mathrm{u}$ niego zweryfikowanych, epidemicznie bezpiecznych komórek, tkanek czy narządów. Terapeutyczne wykorzystanie tkanek, komórek i narządów pochodzenia ludzkiego w ciele człowieka może wywołać zakażenie chorobą. Większości z nich można zapobiec dzięki dokładnej ocenie dawcy i testowaniu zgodnemu $\mathrm{z}$ regułami ustanowionymi i uaktualnianymi według najlepszej dostępnej wiedzy naukowej.

Kwalifikacja (i dyskwalifikacja) dawcy komórek, tkanek i narządów stanowi element tzw. koordynacji pobrania i przeszczepiania u ludzi lub pobrania i zastosowania $\mathrm{u} l u d z \mathrm{i}^{40} \mathrm{i}$ oparta jest na przesłankach natury medycznej, niemających odzwierciedlenia w tekście normatywnym. Decyzja o kwalifikacji komórek, tkanek czy narządów do przeszczepienia konkretnemu biorcy jest decyzją terapeutyczną lekarza, opartą na wskazaniach aktualnej wiedzy medycznej.

${ }^{39}$ D. Rożkiewicz, P. Potocka, E. Ołdak, Podstępna mononukleoza zakaźna, „Pediatria po Dyplomie" 2016, nr 3.

${ }^{40}$ Por. art. 2 ust. 1 pkt 25 ustawy transplantacyjnej. 
W wypadku dawcy zmarłego szpitalny koordynator transplantacyjny gromadzi informacje medyczne o zmarłym i narządach, powstaje charakterystyka zmarłego dawcy zawierająca dane o przebytych i aktualnych chorobach (między innymi o chorobach nowotworowych i zakaźnych), przebytych operacjach. Koordynator gromadzi wyniki badań biochemicznych, obrazowych i czynnościowych, oceniających dawcę i narządy, zleca badania wirusologiczne ( $w$ Polsce obowiązkowo badania w kierunku zakażenia HIV, wirusowego zapalenia wątroby typu B i C, cytomegalii), badania mikrobiologiczne oraz wykonuje (a jeśli nie jest lekarzem - organizuje) szczegółowe badanie przedmiotowe.

Przeciwwskazania do dawstwa ex vivo zostały wskazane w rozporządzeniu Ministra Zdrowia z dnia 25 kwietnia 2006 r. w sprawie wymagań dla kandydata na dawcę komórek, tkanek lub narządu ${ }^{41}$. Kandydata na dawcę dyskwalifikują m.in. choroby zakaźne, z wyjątkiem przypadków gdy biorca przebył tego samego typu schorzenie przenoszone drogą krwiopochodną lub kontaktowa, choroby nowotworowe i nowotwory złośliwe, gąbczaste zwyrodnienie mózgu (TSE) (np. choroba Creutzfeldta-Jakoba, wariant choroby Creutzfeldta-Jakoba), osoby, u których wywiad rodzinny wskazuje na zagrożenie TSE. Jednocześnie regulacja przewiduje, że po przebyciu choroby zakaźnej u kandydatów przeciwwskazania istnieją przez co najmniej dwa tygodnie od chwili pełnego wyleczenia, natomiast w wypadku kilku chorób wymienionych w załączniku do rozporządzenia okresy czasowej dyskwalifikacji są dłuższe, dla przykładu przy zachorowaniu na brucelozę czy boreliozę - 2 lata od daty potwierdzonego wyzdrowienia.

Warto w tym miejscu zaznaczyć, że lekarz, podejmując decyzję o kwalifikacji narządu do przeszczepu, musi uwzględnić niedostateczną pulę dostępnych narządów. Dla zobrazowania sytuacji warto przywołać dane statystyczne, wedle których na przeszczep nerki w październiku $2017 \mathrm{r}$. czekało 1013 osób, natomiast do końca października 2017 r. dokonano 46 przeszczepień nerki od dawców żywych i 841 przeszczepów tego organu od dawców zmarłych ${ }^{42}$. Niedobór narządów do transplantacji skutkuje wzrostem liczby oczekujących i wydłużeniem czasu oczekiwania. Wymusza to podejmowanie decyzji mających na celu zwiększenie liczby pozyskiwanych narządów. Lekarz może w takim wypadku zaordynować

${ }^{41}$ Dz.U. Nr 79, poz. 556.

${ }^{42}$ http://www.poltransplant.org.pl/statystyka_2017.html [dostęp: 2.11.2017 r.]. 
przeszczepienie narządu od dawcy, u którego stwierdzono np. wirusa cytomegalii, istnieją bowiem skuteczne metody profilaktyki, leczenia i monitorowania przeniesionej infekcji, a chory ze schyłkową niewydolnością narządu nie przeżyłby bez przeszczepu zakażonego CMV narządu. Takie decyzje terapeutyczne powinny zawsze być poprzedzone rozważeniem stosunku ryzyka do spodziewanych korzyści dla biorcy.

Dość jednoznacznie sformułowane zostały przesłanki inkluzyjne i ekskluzyjne dla kandydatów na dawcę krwi i dawców krwi. Ustawodawca wskazuje bowiem, że każdorazowe pobranie krwi lub jej składników powinno zostać poprzedzone weryfikacją wypełnionego kwestionariusza dawcy krwi, wywiadem medycznym, badaniami kwalifikacyjnymi, a od kandydata na dawcę krwi lub od dawcy krwi powinna zostać pobrana próbka krwi do badań diagnostycznych w celu ustalenia, czy kandydat na dawcę krwi lub dawca krwi spełnia wymagania zdrowotne i czy pobranie krwi lub jej składników nie spowoduje ujemnych skutków dla jego stanu zdrowia lub stanu zdrowia biorcy $\mathrm{krwi}^{43}$.

Przedstawiciele nauk medycznych zwracają uwagę na to, że „pomimo stosowania bardzo czułych testów w badaniach przeglądowych przed oddaniem krwi przez dawcę nadal niezbędna jest odpowiednia procedura jego kwalifikacji na podstawie wywiadu epidemiologicznego"44. Szczególnie ważna jest przy tym konstrukcja kwestionariusza, który w świetle art. 16 ust. 6 pkt 3 u.p.s.k. powinien zawierać m.in. „istotne dane mogące mieć wpływ na stan zdrowia kandydata na dawcę krwi lub dawcy krwi oraz bezpieczeństwo biorcy krwi". Kryteria wykluczające możliwość bycia dawcą krwi (trwale bądź czasowo) zostały szczegółowo wskazane w rozporządzeniu Ministra Zdrowia z dnia 11 września 2017 r. w sprawie warunków pobierania krwi od kandydatów na dawców krwi i dawców krwi $^{45}$.

W celu weryfikacji, czy kandydat na dawcę krwi lub dawca krwi spełnia wymagania zdrowotne, jednostka organizacyjna publicznej służby krwi jest uprawniona do dostępu do danych zawartych w zgłoszeniach o odnotowanych przypadkach chorób zakaźnych, przetwarzanych w Sy-

${ }^{43}$ Por. art. 15 ust. 1 pkt 3 u.p.s.k.

${ }^{44}$ P. Grabarczyk, A. Kopacz, Bezpieczeństwo przetoczeń krwi pod względem czynników zakaźnych przenoszonych droga krwi w świetle doniesień prezentowanych na 23. Zjeździe Międzynarodowego Towarzystwa Przetaczania Krwi w Amsterdamie, "Journal of Transfusion Medicine" 2014, t. 7, nr 2, s. 62.

${ }^{45}$ Dz.U. poz. 1741. 
stemie Monitorowania Zagrożeń, o którym mowa w art. 26 ustawy z dnia 28 kwietnia 2011 r. o systemie informacji w ochronie zdrowia ${ }^{46}$. Na gruncie ustawy o publicznej służbie krwi został ponadto utworzony odrębny system e-krew zawierający dane kandydatów na dawców krwi i dawców krwi, w tym kandydatów na dawców krwi i dawców krwi, którzy podlegają stałej albo czasowej dyskwalifikacji.

Jednostki organizacyjne publicznej służby krwi zobowiązane są do prowadzenia systemu czuwania nad bezpieczeństwem krwi i jej składników pobranych, badanych, przetwarzanych, przechowywanych, wydawanych lub rozprowadzanych na terytorium $\mathrm{RP}^{47}$. System czuwania ma umożliwić prześledzenie drogi krwi i jej składników od dawcy krwi do jej biorcy i odwrotnie. W literaturze medycznej podkreśla się zasadność bankowania, w ramach systemu czuwania, próbek krwi dawcy i biorcy, pobranych przed transfuzją. Dostępność próbek archiwalnych odgrywa ważną rolę w procesie dochodzenia do przyczyn ewentualnych powikłań, szczególnie przy podejrzeniu potransfuzyjnych chorób wirusowych. Następcze badania próbek archiwalnych mogą potwierdzić lub wykluczyć przeniesienie zakażenia ${ }^{48}$, stanowiąc tym samym doskonały środek dowodowy w sprawach odszkodowawczych.

Przechodząc do mechanizmu zapewnienia bezpieczeństwa epidemicznego biorczyni - a natura rei nie można mówić o biorcach komórek rozrodczych lub zarodków w procedurze medycznie wspomaganej prokreacji - trzeba podkreślić, że ustawodawca jako jeden z kumulatywnych warunków pobrania komórek rozrodczych od dawcy w celu dawstwa partnerskiego oraz innego niż partnerskie wskazał możliwość ograniczenia ryzyka zaistnienia istotnego zdarzenia niepożądanego lub istotnej niepożądanej reakcji u biorczyni oraz u dzieci, które mogą się urodzić w wyniku zastosowania tych komórek rozrodczych w procedurze medycznie wspomaganej prokreacji ${ }^{49}$. Aktualizację tej przesłanki należy stwierdzić $\mathrm{w}$ drodze przeprowadzonego $\mathrm{z}$ kandydatem na dawcę wywiadu medycz-

${ }^{46}$ Tekst jedn., Dz.U. z 2017 r. poz. 1845.

${ }^{47}$ Art. 29a u.p.s.k.

48 Zob. niezwykle interesujące przykłady oraz omówienie międzynarodowego programu pilotażowego bankowania próbek krwi, w którym uczestniczy także Polska: E. Brojer, P. Grabarczyk, P. Zwolińska, A. Bielecka, A. Szczepiński, M. Łętowska, Bankowanie próbek krwi dawców i biorców a podnoszenie bezpieczeństwa przetoczeń krwi, „Journal of Transfusion Medicine" 2011, t. 4, nr 3, passim.

${ }_{49}$ Art. 29 ust. 2 pkt 2 lit. b u.l.n. Analogiczny warunek ustawodawca zastrzegł w odniesieniu do możliwości pobrania komórek rozrodczych od biorczyni w celu zastosowania 
nego oraz niezbędnych badań lekarskich i laboratoryjnych. Normy prawne nie determinują przy tym, które z badań należy uznać za niezbędne w przypadku danego kandydata na dawcę, uzależniając tę kwestię od danych pozyskanych w wywiadzie medycznym lub historii choroby lub historii zdrowia i choroby ${ }^{50}$.

Dokonany przegląd regulacji odnoszących się do bezpieczeństwa epidemicznego komórek (w tym komórek rozrodczych), tkanek (również zarodkowych) i narządów daje podstawę do stwierdzenia, że ustawodawca zasadniczo w sposób wystarczający skonstruował normatywny punkt odniesienia dla minimalizacji zagrożenia przeniesienia czynnika chorobowego z dawcy na biorcę. Oczywiste jest przy tym, że realizacja skonstruowanych $\mathrm{w}$ normach prawnych mechanizmów ochronnych uzależniona jest od adresatów tych norm.

Nie sposób jednakże nie odnotować, że pomimo przyjęcia ustawy o leczeniu niepłodności jako regulacji dotyczących dawstwa komórek rozrodczych w płaszczyźnie krajowej, czego wymagała dyrektywa 2004/23/WE, ustawa ta nie objęła swym normowaniem problematyki transplantacji narządów rozrodczych lub ich części. Przypomnijmy, zakres ten został jednocześnie wyłączony spod zastosowania ustawy transplantacyjnej - jej art. 1 ust. 2 pkt 1 . W ten sposób mamy do czynienia z sytuacją że legalny i możliwy z punktu widzenia nauk medycznych przeszczep np. macicy ${ }^{51}$, jajników, jąder nie jest objęty przepisami gwarantującymi ochronę biorców, zakotwiczonymi w ustawie transplantacyjnej czy ustawie o leczeniu niepłodności. Gwarancyjną funkcję będą w tym wypadku pełniły przepisy rozdziału 3 u.z.z.z.ch.z. o zapobieganiu szerzenia się zakażeń związanych z udzielaniem świadczeń zdrowotnych oraz innych czynności, w trakcie wykonywania których dochodzi do naruszenia ciągłości tkanek ludzkich.

Podsumowując rozważania poczynione w niniejszym opracowaniu, wypada stwierdzić, że adresowany do władz publicznych konstytucyjny obowiązek zwalczania chorób epidemicznych jest realizowany przez le-

$\mathrm{w}$ procedurze medycznie wspomaganej prokreacji $\mathrm{w}$ dawstwie partnerskim albo dawstwie innym niż partnerskie (art. 32 ust. 1 u.l.n.).

${ }^{50}$ Zob. rozporządzenie Ministra Zdrowia z dnia 23 października 2015 r. w sprawie wymagań zdrowotnych dla kandydata na dawcę komórek rozrodczych w celu dawstwa partnerskiego i dawstwa innego niż partnerskie oraz dla biorczyni komórek rozrodczych i zarodków oraz szczegółowych warunków pobierania komórek rozrodczych w celu zastosowania $\mathrm{w}$ procedurze medycznie wspomaganej prokreacji.

${ }^{51}$ Więcej zob. M. Młot, Transplantacja macicy ex vivo w świetle prawa polskiego, „Prawo i Medycyna" 2016, nr 2, passim. 
gislatywę także na płaszczyźnie przeciwdziałania przenoszeniu czynnika chorobowego od dawcy do biorcy w terapeutycznych procedurach transplantacyjnych. Przepisy odnoszące się do epidemicznego bezpieczeństwa biorców rozproszone są w różnych aktach normatywnych regulujących zastosowanie różnego rodzaju komórek, tkanek i narządów ludzkich i dotyczą zarówno aspektów organizacji jednostki, w której dokonuje się pobrania i transplantacji, jak również wymogów względem personelu uczestniczącego $\mathrm{w}$ procedurach medycznych zmierzających do przeniesienia komórek, tkanek, narządów od dawcy do biorcy, jak również kryteriów kwalifikacji i ekskluzyjnych wobec kandydatów na dawców.

Na koniec wreszcie nie można pominąć tego, iż na wymiar i intensywność ochrony epidemicznej biorców przeszczepów wpływają także normy prawne przyjmowane na płaszczyźnie regionalnej (w szczególności unijnej) oraz globalnej. Aktywność organów ponadnarodowych w żadnym razie nie wyręcza władz krajowych w przyjmowaniu rozwiązań służących realizacji obowiązków ochrony praw podmiotowych (w perspektywie problematyki podejmowanej $\mathrm{w}$ niniejszym opracowaniu - prawa do ochrony zdrowia i skorelowanego z nim obowiązku władzy publicznej zwalczania chorób epidemicznych) ${ }^{52}$.

Słowa kluczowe: choroby zakaźne, biorcy ludzkich komórek, tkanek i narządów, transplantacje.

\section{Bibliografia}

Bosek L., Komentarz do art. 68, [w:] M. Safjan, L. Bosek (red.), Konstytucja RP. Tom I. Komentarz Art. 1-86, Warszawa 2016.

Brojer E., Grabarczyk P., Zwolińska P., Bielecka A. Szczepiński A., Łętowska M., Bankowanie próbek krwi dawców i biorców a podnoszenie bezpieczeństwa przetoczeń krwi, „Journal of Transfusion Medicine” 2011, t. 4, nr 3.

Grabarczyk P., Kopacz A., Bezpieczeństwo przetoczeń krwi pod względem czynników zakaźnych przenoszonych droga krwi w świetle doniesień prezentowanych

52 Wątpliwość co do tego, czy nie dochodzi do „rozcieńczenia” konstytucyjnych obowiązków władz krajowych w zakresie ochrony praw podmiotowych, wyraził G. Scheu, In Dubio Pro Securitate. Contergan, Hepatitis-/AIDS-Blutprodukte, Spongiformer Humaner Wahn Und kein Ende? Grundrechtliche Gefahrenvorsorge für Leib und Leben im Recht der Produkt- und Arzneimittelsicherheit - auch unter Aspekten der Europäisierung und Globalisierung, Baden Baden 2003, s. 278-279. 
na 23. Zjeździe Międzynarodowego Towarzystwa Przetaczania Krwi w Amsterdamie, ,Journal of Transfusion Medicine" 2014, t. 7, nr 2.

Haberko J., Uhrynowska-Tyszkiewicz I., Ustawa o pobieraniu, przechowywaniu i przeszczepianiu komórek, tkanek i narządów. Komentarz, Warszawa 2014.

Opałek K., Wróblewski J., Zagadnienia teorii prawa, Warszawa 1969.

Młot M., Transplantacja macicy ex vivo w świetle prawa polskiego, „Prawo i Medycyna" 2016, nr 2.

Prokop K., Prawo do ochrony zdrowia w świetle art. 68 Konstytucji RP, [w:] T. Mróz, U. Drozdowska (red.), Uwarunkowania prawne, ekonomiczne i socjologiczne funkcjonowania wybranych systemów ochrony zdrowia, Białystok 2011.

Porta M., A Dictionary of Epidemiology, Oxford 2008.

Rożkiewicz D., Potocka P., Ołdak E., Podstępna mononukleoza zakaźna, „Pediatria po Dyplomie" 2016, nr 3.

Scheu G., In Dubio Pro Securitate. Contergan, Hepatitis-/AIDS-Blutprodukte, Spongiformer Humaner Wahn Und kein Ende? Grundrechtliche Gefahrenvorsorge für Leib und Leben im Recht der Produkt- und Arzneimittelsicherheit - auch unter Aspekten der Europäisierung und Globalisierung, Baden Baden 2003.

Trzciński J., Wiącek M., Komentarz do art. 68, [w:] L. Garlicki, M. Zubik (red.), Konstytucja Rzeczypospolitej Polskiej. Komentarz. Tom II, Warszawa 2016.

\section{LEGAL INSTRUMENTS SUPPORTING EPIDEMIC SAFETY OF RECIPIENTS OF HUMAN CELLS, TISSUES AND ORGANS}

\section{S u m m a r y}

The study discusses the implementation of constitutional obligation of public authorities to combat epidemic illnesses at the level of counteracting the transmission of disease agent from donor to recipient in therapeutic transplantation procedures. It was pointed out that the provisions relating to the epidemiological safety of recipients are dispersed in various normative acts regulating the use of different types of cells, tissues and organs of humans, and relate both to the aspects of the organization of the transplantation unit as well as to the personnel involved in the medical procedures. intended to transfer cells, tissues, organs from the donor to the recipient, as well as eligibility and exclusion criteria for candidates for donors.

Key words: infectious diseases, recipient of human cells, tissues and organs, transplantation. 


\section{ПРАВОВЫЕ ИНСТРУМЕНТЫ, КОТОРЫЕ ПОДДЕРЖИВАЮТ ЭПИДЕМИЧЕСКУЮ БЕЗОПАСНОСТЬ РЕЦИПИЕНТОВ ЧЕЯОВЕЧЕСКИХ КАЕТОК, ТКАНЕЙ И ОРГАНОВ}

$$
\text { P е } 3 \text { ю м е }
$$

В данной работе был обсужден способ реализации конституционного обязательства органов государственной власти в борьбе с эпидемическими болезнями в области противодействия переноса болезненного компонента от донора к реципиенту в терапевтических трансплантационных процедурах. Указано, что положения, касающиеся эпидемической безопасности реципиента, разбросаны во многих нормативных актах, которые регулируют использование разного вида клеток, тканей и человеческих органов и касаются одинаково аспектов организации единицы, в которой осуществляются сборы и трансплантации, также как требований относительно персонала, который участвует в медицинских процедурах связанных с переносом клеток, тканей, органов от донора к реципиенту, а также критериев квалификации и эксклюзивных по отношению к кандидатам на донора.

Ключевые слова: инфекционные болезни, реципиенты человеческих клеток, тканей и органов, трансплантации. 